УДК 341.21

DOI https://doi.org/10.32849/2663-5313/2020.7.71

\title{
Руфат Мірзоєв,
}

аспірант кафедри міжнародно-публічного права

Національного юридичного університету імені Ярослава Мудрого

\section{ДВОСТОРОННІ МІЖНАРОДНІ ДОГОВОРИ УКРАЇНИ У СФЕРІ ТРАНСКОРДОННОГО СПІВРОБІТНИЦТВА}

У статті досліджуються особливості двосторонніх міжнародних договорів у сфері транскордонного співробітниитва, учасником яких є Україна. Міжнародно-правову основу для транскордонного співробітництва України із сусідніми держсвами складають відповідні статті (норми) у двосторонніх міжнародних договорах про відносини добросусідства та співробітниитва. А саме стаття 10(1) Договору між Україною і Республікою Польщею про добросусідство, дружні відносини і співробітниитво 1992 р., стаття 8 Договору про добросусідство, дружні відносини і співробітниитво між Украйною та Словацькою Республікою 1993 р., стаття 8 Договору про основи добросусідства та співробітниитва між Украӥною і Угорською Республікою 1991 р., стаття 10(1) Договору про відносини добросусідства і співробітниитва між Україною та Румунією 1997 р., стаття 12 Договору про добросусідство, дружбу і співробітниитво між Україною та Республікою Молдова 1992 р. і стаття 10 Договору про дружбу, добросусідство і співробітниитво між Україною і Республікою Білорусь 1995 р. 3 Російською Федерачією Україна припинила дію відповідного договору у 2019 р. з причини істотного порушення Російською Федерачією положень договору. Доведено, що зазначені статті (норми) можна вважати угодами першого типу, а саме угодами про розвиток транскордонного співробітниитва. Встановлено, що з деякими сусідніми державами (з Республікою Польща, з Республікою Молдова, з Республікою Білорусь і з Російською Федерачією) Україна уклала міжнародні договори про транскордонне співробітництво другого типу, а саме міжурядові угоди про регіональні транскордонні зв'язки. Зазвичай такі міжурядові угоди містять посилання на відповідні двосторонні міжнародні договори про відносини добросусідства та співробітниитва, а також спеиіальні норми, які сприяють розвитку прикордонних регіонів у певних галузях, що становлять взаємний інтерес. Визначено, що міжнародно-правову основу для транскордонного співробітниитва між Україною та Європейським Союзом, як самостійним суб'єктом права, складає Угода про асочіачію між Україною, з однієї сторони, та Європейським Союзом, Свропейським співтовариством з атомної енергетики $і$ їх державами-иленами, з іншої сторони, 2014 р., зокрема преамбула і Глава 27 иієі Угоди «Транскордонне та регіональне співробітниитво».

Ключові слова: Європейська рамкова конвенція про транскордонне співробітництво, Угода про асоціацію між Україною та Європейським Союзом, територіальні общини та власті, міждержавні угоди про розвиток транскордонного співробітництва, міждержавні угоди про регіональні транскордонні зв'язки.

Постановка проблеми. Поява і розвиток транскордонного співробітництва є одним із безпосередніх наслідків розвитку сучасних міжнародних відносин, збільшення значення громадянського суспільства і підвищення ролі територіальних общин і властей. У свою чергу відносини у сфері транскордонного співробітництва потребують відповідного правового регулювання. Європейська рамкова конвенція про транскордонне співробітництво між територіальними общинами або властями від 21.05.1980 р. у статті 3(2) передбачає укладення міждержавних угод, в яких, окрім іншого, можуть визначатися контекст, форми та межі, в яких можуть здійснювати свою діяльність територіальні общини та власті, зацікавлені у транскордон- ному співробітництві [1, ст. 3(2)]. Відповідно міжнародна практика України містить низку міжнародних договорів двостороннього характеру у сфері транскордонного співробітництва, які потребують спеціальних науково-практичних досліджень задля якомога кращого забезпечення інтересів українських територіальних общин і властей.

Аналіз останніх досліджень і публікацій. Окремі аспекти міжнародних договорів України у сфері транскордонного співробітництва досліджували такі українські вчені, як: колектив авторів під керівництвом I.В. Артьомова [2], М.О. Баймуратов і Є.О. Васильєв [3] П.Ю. Бєлєнький [4], Є.А. Василькова [5], Ф.Г. Ващук і О.М. Ващук [6], I.В. Жилінкова [7], Я.Й. Малик і О.І. Береза [8], В.В. Засадко 
[9], Н.А. Мікула [4; 9; 10], Р.Ш. огли Мірзоєв [11; 12], В.М. Монастирний [13], T.I. Ренькас [14], Ю.С. Рогозян [15], І.В. Студенніков [16], колектив авторів: В.В. Толкованов [10], А.О. Краснейчук, О.Ю. Амосов і Н.Л. Гаркалова [17], Ю. Ткаченко і В. Пустовар [18] та інші. Однак комплексно зміст двосторонніх міжнародних договорів України у сфері транскордонного співробітництва досліджується уперше.

Мета статті полягає у встановленні особливостей двосторонніх міжнародних договорів у сфері транскордонного співробітництва, учасником яких є Україна. Для досягнення цієї мети слід вирішити такі завдання:

- встановити коло двосторонніх міжнародних договорів України у сфері транскордонного співробітництва;

- з'ясувати види двосторонніх міжнародних договорів України у сфері транскордонного співробітництва;

- визначити особливості двосторонніх міжнародних договорів України у сфері транскордонного співробітництва.

Виклад основного матеріалу. Додаток 1 до Європейської рамкової конвенції про транскордонне співробітництво між територіальними общинами або властями від 21.05.1980 р. передбачає декілька типів міжнародних угод у сфері транскордонного співробітництва [1], переважна більшість з яких є угодами приватного характеру [12]. I лише два типи (види) міжнародних угод з Додатку 1 до Свропейської рамкової конвенції про транскордонне співробітництво між територіальними общинами або властями від 21.05.1980 р. є міждержавними угодами публічного характеру, укладення яких належить виключно до компетенції держави, - це угоди про розвиток транскордонного співробітництва та угоди про регіональні транскордонні зв'язки [1].

Критерії розмежування міжнародних угод публічного і приватного характеру у сфері транскордонного співробітництва пояснюється у Висновку 24(2004) до проекту звіту Комітету регіонів СС стосовно нового правового інструменту для транскордонного співробітництва [19]. Зокрема пункт 14 цього Висновку визначає, що Європейська рамкова конвенція про транскордонне співробітництво [20] і протоколи до неї [21; 22; 23] відносять поняття «транскордонне співробітництво» («transfrontier co-operation») і поняття «міжтериторіальне співробітництво» («interterritorial cooperation») для зовнішніх зв’язків між місцевими та регіональними властями, які не входять до обсягу міжнародного права, і відповідно не можуть бути його прямим суб'єктом. У той час як держави можуть укладати угоди, що стосуються способів транскордонного співробітництва між територіальними властями, Європейська рамкова конвенція про транскордонне співробітництво передбачає «домовленості», що укладаються між територіальними властями. Зазначені домовленості не є предметом міжнародного публічного права. Якщо угоди між державами існують, вони закладають умови для транскордонного співробітництва і форми, які таке співробітництво може приймати, але не роблячи таке співробітництво об'єктом публічного права.

Подібне розуміння щодо розмежування міжнародних угод публічного і приватного характеру у сфері транскордонного співробітництва знаходить підтвердження і у вітчизняній правовій доктрині [7, с. 76-78; 17 , c. $15 ; 24$, c. 34$]$.

Предметом нашої статті є саме міждержавні двосторонні договори публічного характеру про транскордонне співробітництво, які Україна уклала з усіма сусідніми державами.

Перший тип (вид) таких міждержавних договорів - це угоди про розвиток транскордонного співробітництва. Разом з тим слід зазначити, що це не спеціальні міжнародні договори про транскордонне співробітництво, а окремі статті (норми) у двосторонніх міжнародних договорах про відносини добросусідства та співробітництва. Однак саме ці окремі статті (норми) закладають основи транскордонного співробітництва України із сусідніми державами.

Розглянемо спочатку відповідні міжнародно-правові підстави для транскордонного співробітництва України з державами - членами Свропейського Союзу. Згідно зі статтею 10(1) Договору між Україною i Республікою Польщею про добросусідство, дружні відносини і співробітництво від 18 травня 1992 р. «Сторони сприятимуть встановленню і розвиткові безпосередніх зв'язків та співробітництва між регіонами, адміністративно-територіальними одиницями та містами України і Республіки Польщі. Особлива увага приділятиметься прикордонному співробітництву. Сторони співпрацюватимуть у галузі перспективного планування розвитку прикордонних регіонів» [25, ст. 10(1)]. У статті 8 Договору про добросусідство, дружні відносини і співробітництво між Україною та Словацькою Республікою від 29 червня 1993 р. встановлено, що «Договірні Сторони всіляко сприятимуть розвитку постійних і прямих контактів між ... між місцевими органами самоврядування та їх представниками» 
[26, ст. 8]. Відповідно до статті 8 Договору про основи добросусідства та співробітництва між Україною і Угорською Республікою від 6 грудня 1991 р. «Договірні Сторони всіляко сприятимуть розвиткові контактів між ... регіональними та місцевими органами самоврядування та їх керівниками на постійній, регулярній основі. Сторони також заохочуватимуть прикордонне співробітництво у всіх галузях» [27, ст. 8]. У статті 10(1) Договору про відносини добросусідства і співробітництва між Україною та Румунією від 2 червня 1997 р. передбачено, що «Для забезпечення розвитку та поглиблення двосторонніх відносин, а також взаємного обміну думками 3 міжнародних питань, Договірні Сторони будуть сприяти регулярним контактам між їх центральними та місцевими установами» [28, ст. 10(1)]

Зважаючи на завдання нашої статті, доречно також зупинитися на Угоді про асоціацію між Україною, з однієї сторони, та Європейським Союзом, Європейським співтовариством 3 атомної енергетики i їх державами-членами, з іншої сторони, від 21 березня 2014 р. і 27 червня 2014 р. [29], оскільки за своєю правовою природою Угода про асоціацію між Україною та ЄС також $\epsilon$ двостороннім міжнародним договором [30, с. 268]. Преамбула Угоди про асоціацію містить загальне зобов’язання підтримувати транскордонне та міжрегіональне співробітництво, а Глава 27 «Транскордонне та регіональне співробітництво» (статті 446-449) [29, ст. 446-449] - норми спеціального характеру щодо транскордонного співробітництва між Україною та Європейським Союзом, як самостійним суб'єктом права.

Зокрема Угодою про асоціацію передбачається формування та реалізація регіональних політик, багаторівневого управління та партнерства, $з$ особливим наголосом на розвитку відсталих територій та на територіальному співробітництві, забезпечення зміцнення транскордонних і регіональних економічних зв'язків та ділового партнерства, зміцнення та заохочення розвитку таких складових транскордонного та регіонального співробітництва, як, inter alia, транспорт, енергетика, комунікаційні мережі, культура, освіта, туризм, охорона здоров'я та інших сфер, охоплених цією Угодою, які містять елементи транскордонного та регіонального співробітництва [29, ст. 446-449].

Міжнародно-правові підстави для транскордонного співробітництва України з державами - учасниками СНД також містяться в окремих статтях (нормах) двосторонніх міжнародних договорів про відносини добросусідства та співробітництва. Так, згідно зі статтею 12 Договору про добросусідство, дружбу і співробітництво між Україною та Республікою Молдова від 23 жовтня 1992 р. «Договірні Сторони всіляко сприятимуть розвиткові контактів між ... регіональними і місцевими органами самоврядування та їх керівниками на постійній, регулярній основі. Сторони також заохочуватимуть прикордонне співробітництво в різних сферах» [31, ст. 12]. Відповідно до статті 10 Договору про дружбу, добросусідство і співробітництво між Україною і Республікою Білорусь від 17 липня 1995 р. «Високі Договірні Сторони приділяють особливу увагу розвитку економічних зв'язків між прикордонними районами обох держав, а також забезпечують сприятливі умови для співробітництва на рівні адміністративно-територіальних одиниць в рамках їхньої компетенції» [32, ст. 10].

Окремо слід зазначити, що стаття 14 Договору про дружбу, співробітництво і партнерство між Україною та Російською Федерацією від 31 травня 1997 р. також передбачала, що «Високі Договірні Сторони забезпечать сприятливі умови для прямих торговельних та інших економічних відносин і співробітництва на рівні адміністративно-територіальних одиниць відповідно до діючих національних законодавств, приділяючи особливу увагу розвитку економічних зв'язків прикордонних регіонів» [33, ст. 14]. Але 31 квітня 2019 р. Україна припинила дію зазначеного Договору з причини істотного порушення Російською Федерацією положень договору, а саме через збройну агресію Російської Федерації проти України [34, ст. 1].

3 деякими сусідніми державами Україна уклала міжнародні угоди про транскордонне співробітництво другого типу (виду), а саме міжурядові угоди про регіональні транскордонні зв'язки. Маються на увазі такі міжнародні договори: Угода між Урядом України та Урядом Республіки Польща про міжрегіональне співробітництво від 24 травня 1993 р. [35], Угода між Урядом України та Урядом Республіки Молдова про співробітництво прикордонних областей України та адміністративно-територіальних одиниць Республіки Молдова від 11 березня 1997 р. [36], Угода між Урядом України та Урядом Республіки Білорусь про співробітництво прикордонних областей України та Республіки Білорусь від 12 травня 1997 р. [37], Угода між Кабінетом Міністрів України та Урядом Республіки Білорусь про міжрегіональне та прикордонне співробітництво між Україною та Республікою Білорусь від 22 травня 2013 р. [38], Угода між Урядом України та Урядом Російської Федерації про співробітництво прикордонних областей України 
та Російської Федерації від 27 січня 1995 р. [39] та Угода між Кабінетом Міністрів України та Урядом Російської Федерації про міжрегіональне та прикордонне співробітництво між Україною та Російською Федерацією від 27 жовтня 2010 р. [40].

Практично усі зазначені міжурядові угоди містять посилання на відповідні двосторонні міжнародні договори про відносини добросусідства та співробітництва. Лише У года між Урядом України та Урядом Республіки Молдова про співробітництво прикордонних областей України та адміністративно-територіальних одиниць Республіки Молдова від 11 березня 1997 р. [36] не містить прямого посилання на Договір про добросусідство, дружбу і співробітництво між Україною та Республікою Молдова від 23 жовтня 1992 р. [31], однак преамбула Угоди від 11 березня 1997 р. [36] містить вказівку на «добросусідські відносини, що історично склалися, високий ступінь інтегрування економік держав».

Усі зазначені міжурядові угоди містять спеціальні норми, які сприяють розвитку прикордонних регіонів у певних галузях, насамперед, йдеться про перевезення пасажирів і вантажів, торгівлю, виробничу кооперацію, сільське господарство, охорону навколишнього середовища, освіту, культуру, охорону здоров'я, широкий інформаційний обмін та інші питання, що становлять взаємний інтерес.

\section{Висновки}

Міжнародно-правову основу для транскордонного співробітництва України із сусідніми державами складають відповідні статті (норми) у двосторонніх міжнародних договорах про відносини добросусідства та співробітництва. Зазначені статті (норми) можна вважати угодами першого типу (виду), а саме угодами про розвиток транскордонного співробітництва. Такі двосторонні міжнародні договори Україна уклала з усіма сусідніми державами. 3 Російською Федерацією Україна припинила дію відповідного договору з 1 квітня 2019 р. $з$ причини істотного порушення Російською Федерацією положень договору.

3 деякими сусідніми державами (з Республікою Польща, з Республікою Молдова, з Республікою Білорусь і з Російською Федерацією) Україна уклала міжнародні договори про транскордонне співробітництво другого типу (виду), а саме міжурядові угоди про регіональні транскордонні зв'язки. Зазвичай такі міжурядові угоди містять посилання на відповідні двосторонні міжнародні договори про відносини добросусідства та співробітни- цтва, а також спеціальні норми, які сприяють розвитку прикордонних регіонів у певних галузях, що становлять взаємний інтерес.

Міжнародно-правову основу для транскордонного співробітництва між Україною та Європейським Союзом, як самостійним суб'єктом права, складає Угода про асоціацію між Україною, з однієї сторони, та Європейським Союзом, Європейським співтовариством з атомної енергетики і їх державамичленами, 3 іншої сторони, від 21 березня 2014 р. і від 27 червня 2014 р., зокрема преамбула і Глава 27 цієї Угоди «Транскордонне та регіональне співробітництво».

Перспективи подальших розвідок у даному науковому напрямку, на нашу думку, полягають у необхідності дослідження практики транскордонного співробітництва України.

\section{Список використаних джерел:}

1. Європейська рамкова конвенція про транскордонне співробітництво між територіальними общинами або властями (ETS № 106). Вчинено у м. Мадрид 21.05.1980 p. URL: http://zakon.rada.gov.ua/laws/show/995_106/ conv (дата звернення: 03.07.2020).

2. Транскордонне співробітництво України: стан, проблеми, перспективи: монографія / за заг. ред. І.В. Артьомова. Ужгород: МПП «Гражда», 2012. $520 \mathrm{c}$.

3. Баймуратов М.О., Васильєв Є.О. Територіальна громада та органи місцевого самоврядування України у локальній системі зовнішньоекономічної діяльності: монографія; за ред.: Ю.О. Волошина, Б.Я. Кофмана; Ін-т законодавства Верховної Ради України, Європ. орг. публіч. права України. Одеса: Фенікс, 2017. 216 с.

4. Бєлєнький П.Ю., Мікула Н.А. Зовнішньоекономічна діяльність регіонів: монографія / Регіональна політика: методологія, методи, практика: [кол. авт.; за ред. академіка НАНУ М. І. Долішного]. Львів: НАН України; Інститут регіональних досліджень, 2001. 870 с.

5. Василькова Є.А. Європейська (рамкова) конвенція про транскордонне співробітництво між територіальними общинами або властями 1980 року: спроба системного аналізу. Науковий вісник Академії муніиипального управління: збірник наукових пращь. Серія «Право». 2011. Вип. 2. C. 81-92. URL: http://nbuv.gov.ua/UJRN/Nvamu_ pr_2011_2_9 (дата звернення: 03.07.2020).

6. Ващук Ф.Г., Ващук О.М. Актуальні аспекти нормативно-правового забезпечення транскордонного співробітництва України // Ефективність транскордонного співробітництва через міжнародний моніторинг та координацію діяльності національних суб'єктів: матер. міжнар. наук.-практ. конф. (8-9 квітня 2011 р., м. Ужгород). Ужгород: [б. в.], 2011. С. 39-55. URL: https://www.uzhnu.edu.ua/uk/infocentre/get/3808 (дата звернення: 03.07.2020). 
7. Жилінкова I.В. Транскордонне співробітництво суб'єктів місцевого самоврядування місцевого самоврядування. Державне будівниитво та місиеве самоврядування. Вип. 7. 2004. C. 74-81. URL: http://dspace.nlu.edu.ua/ bitstream/123456789/2469/1/Zhylinkova 74.pdf (дата звернення: 03.07.2020).

8. Малик Я.Й., Береза О.І. Нормативноправове забезпечення транскордонного співробітництва України. Ефективність державного управління. 2013. Вип. 35. С. 13-19. URL: http:// nbuv.gov.ua/UJRN/efdu_2013_35_3 (дата звернення: 03.07.2020)

9. Мікула Н.А., Засадко В.В. Транскордонне співробітництво України в контексті євроінтеграції: монографія. Київ: НІСД, 2014. 316 с.

10. Мікула Н.А., Толкованов В.В. Транскордонне співробітництво: посібник. Київ: Крамар, 2011. $259 \mathrm{c}$.

11. Mirzoiev Rufat. The comparative study of the concepts «transfrontier» and «cross-border» cooperation in the documents of the Council of Europe and the European Union. Evropsky politický a prázní diskurz / European political and law discourse. 2020. Vol. 7 Iss. 2. P. 24-31. DOI: 10.46340/eppd.2020.7.2.3 URL: https://eppd13.cz/ wp-content/uploads/2020/2020-7-2/05.pdf (дата звернення: 03.07.2020).

12. Mirzoiev Rufat.Agreements and arrangements concluded by territorial communities or authorities in the field of transfrontier co-operation. Visegrad journal on human rights. 2020. № 2. P. 105-110. URL: http://vjhr.sk/archive/2020_2/part_3/18.pdf (дата звернення: 03.07.2020).

13. Монастирний В.М. Шляхи вдосконалення державного регулювання міжрегіонального співробітництва. Актуальні проблеми державного управління. 2013. № 2. С. 97-104. URL: http:// nbuv.gov.ua/UJRN/apdy 2013215 (дата звернення: 03.07.2020).

14. Ренькас T.I. Міжрегіональне співробітництво західних областей України: становлення і перспективи розвитку: автореф. дис. ... канд. наук з держ. упр. Київ 2018. 24 c. URL: http://ipk.edu.ua/ wp-content/uploads/2019/05/AVTOREFERATREN-KAS.pdf (дата звернення: 03.07.2020).

15. Рогозян Ю.С. Нормативне забезпечення міжрегіонального співробітництва. Економіка та право. 2015. № 3 (42). С. 70-76.

16. Студенніков I.В. Транскордонне співробітництво як джерело регіональної політики в України. Економічний часопис - XXI. 2005. № $1 / 2$. URL http://soskin.info/ea/2005/1-2/20050111.html (дата звернення: 03.07.2020).

17. Транскордонне співробітництво в системі регіонального розвитку України: наук. розробка / В.В. Толкованов, А.О. Краснейчук, О.Ю. Амосов, Н.Л. Гаркалова; за заг. ред. В.В. Толкованова, А.О. Краснейчук. Київ: НАДУ, 2015. 44 с.

18. Tkachenko Yu., Pustovar V. Approaches to the Definition of Cross-Border Cooperation: Discussion Points. The Russian Academic Journal. 2014. Vol. 29. № 3. P. 39-42. URL: http://oaji.net/ articles/2014/1391-1417702602.pdf （дата звернення: 03.07.2020).

19. Opinion 24(2004) on the draft outlook report of the Committee of the Regions on a new legal instrument for cross-border co-operation. Adopted by 11th Session, 25 to 27 May 2004, Congress of Local and Regional Authorities of Europe, Council of Europe. URL: https://rm.coe.int/opinion-of-thecongress-of-local-and-regional-authorities-on-the$\mathrm{draft} / 1680719340$ (дата звернення: 03.07.2020).

20. European Outline Convention on Transfrontier Co-operation between Territorial Communities or Authorities (ETS No. 106), Madrid, 21.V.1980. URL: https://www.coe.int/ en/web/conventions/full-list/-/conventions/ treaty/106 (дата звернення: 03.07.2020).

21. Additional Protocol to the European Outline Convention on Transfrontier Co-operation between Territorial Communities or Authorities (ETS No. 159), Strasbourg, 09/11/1995. URL: https://www.coe.int/en/web/conventions/fulllist/-/conventions/treaty/159 (дата звернення: 03.07.2020).

22. Protocol No. 2 to the European Outline Convention on Transfrontier Co-operation between Territorial Communities or Authorities concerning interterritorial co-operation (ETS No. 169), Strasbourg, 05/05/1998. URL: https://www.coe.int/ en/web/conventions/full-list/-/conventions/ treaty/169 (дата звернення: 03.07.2020).

23. Protocol No. 3 to the European Outline Convention on Transfrontier Co-operation between Territorial Communities or Authorities concerning Euroregional Co-operation Groupings (ECGs) (CETS No. 206), Utrecht, 16/11/2009. URL: https://www.coe.int/en/web/conventions/fulllist/-/conventions/treaty/206 (дата звернення: 03.07.2020).

24. Міжнародне право: навч. посібник / за ред. М.В. Буроменського. Київ: Юрінком Інтер, 2006. $336 \mathrm{c}$.

25. Договір між Україною і Республікою Польщею про добросусідство, дружні відносини і співробітництво. Здійснено у м. Варшаві 18 травня 1992 p. URL: https://zakon.rada.gov.ua/ laws/show/616 172 (дата звернення: 03.07.2020).

26. Договір про Договір про добросусідство, дружні відносини і співробітництво між Україною та Словацькою Республікою. Здійснено в м. Києві 29 червня 1993 p. URL: https://zakon.rada.gov.ua/ laws/show/703_150 (дата звернення: 03.07.2020).

27. Договір про основи добросусідства та співробітництва між Україною і Угорською Республікою. Здійснено в м. Києві 6 грудня 1991 p. URL: https://zakon.rada.gov.ua/laws/ show/348_004 (дата звернення: 03.07.2020).

28. Договір про відносини добросусідства і співробітництва між Україною та Румунією. Вчинено в м. Констанца 2 червня 1997 р. URL https://zakon.rada.gov.ua/laws/show/642_003 (дата звернення: 03.07.2020).

29. Угода про асоціацію між Україною, з однієї сторони, та Європейським Союзом, Європейським 
співтовариством 3 атомної енергетики і їх державами-членами, з іншої сторони, від 21 березня 2014 р. і від 27 червня 2014 р. URL: https:// zakon.rada.gov.ua/laws/show/984_011\#Text (дата звернення: 03.07.2020).

30. Стешенко B.M. Правовий статус Угоди про асоціацію між Україною та Свропейським Союзом. Юридичний науковий електронний жур нал. 2014. № 6. С. 267-269. URL: http://sej.org. ua/6_2014/74.pdf (дата звернення: 03.07.2020).

31. Договір про добросусідство, дружбу i співробітництво між Україною та Республікою Молдова. Здійснено 23 жовтня 1992 р. URL https://zakon.rada.gov.ua/laws/show/498_161 (дата звернення: 03.07.2020).

32. Договір про дружбу, добросусідство i співробітництво між Україною і Республікою Білорусь. Вчинено в м. Мінську 17 липня 1995 p. URL: https://zakon.rada.gov.ua/laws/ show/112 692 (дата звернення: 03.07.2020).

33. Договір про дружбу, співробітництво і партнерство між Україною та Російською Федерацією. Вчинено у м. Києві 31 травня 1997 p. URL: https://zakon.rada.gov.ua/laws/ show/643_006 (дата звернення: 03.07.2020).

34. Про припинення дії Договору про дружбу, співробітництво і партнерство між Україною і Російською Федерацією: Закон України від 06.12.2018 р. № 2643-VIII. URL: https:// zakon.rada.gov.ua/laws/show/2643-19 (дата звернення: 03.07.2020).

35. Угода між Урядом України та Урядом Республіки Польща про міжрегіональне співробітництво. Здійснено в м. Києві 24 травня
1993 p. URL: https://zakon.rada.gov.ua/laws/ show/616 171 (дата звернення: 03.07.2020).

36. Угода між Урядом України та Урядом Республіки Молдова про співробітництво прикордонних областей України та адміністративнотериторіальних одиниць Республіки Молдова. Вчинено в м. Кишиневі 11 березня 1997 p. URL: https://zakon.rada.gov.ua/laws/show/498_026 (дата звернення: 03.07.2020).

37. Угода між Урядом України та Урядом Республіки Білорусь про співробітництво прикордонних областей України та Республіки Білорусь. Вчинено 12 травня 1997 p. URL: https:// zakon.rada.gov.ua/laws/show/112_006 (дата звернення: 03.07.2020).

38. Угода між Кабінетом Міністрів України та Урядом Республіки Білорусь про міжрегіональне та прикордонне співробітництво між Україною та Республікою Білорусь. Учинено в м. Києві 22 травня 2013 р. URL: https://zakon.rada.gov.ua/ laws/show/112_190 (дата звернення: 03.07.2020).

39. Угода між Урядом України та Урядом Російської Федерації про співробітництво прикордонних областей України та Російської Федерації. Вчинено в м. Харкові 27 січня 1995 р. URL: https://zakon.rada.gov.ua/laws/show/643 702 (дата звернення: 03.07.2020).

40. Угода між Кабінетом Міністрів України та Урядом Російської Федерації про міжрегіональне та прикордонне співробітництво між Україною та Російською Федерацією. Вчинено в м. Києві 27 жовтня 2010 p. URL: https://zakon.rada.gov.ua/ laws/show/643_412 (дата звернення: 03.07.2020).

Rufat Mirzoiev. Bilateral international agreements of Ukraine in the area of cross-border cooperation

The paper examines the features of bilateral treaties in the field of transfrontier cooperation, concluded by Ukraine. The international legal bases for transfrontier cooperation of Ukraine with neighboring states are the relevant articles (norms) in bilateral treaties on good neighborly relations and cooperation. Namely, Article 10 (1) of the Treaty between Ukraine and the Republic of Poland on Good Neighborliness, Friendly Relations and Cooperation (1992), Article 8 of the Treaty between Ukraine and the Slovak Republic on Good Neighborliness, Friendly Relations and Cooperation (1993), Article 8 of the Treaty between Ukraine and the Republic of Hungary on the Neighborhood and Cooperation (1991), Article 10(1) of the Treaty between Ukraine and Romania on Good Neighborliness and Cooperation (1997), Article 12 of the Treaty between Ukraine and the Republic of Moldova on Good Neighborliness, Friendship and Cooperation (1992) and Article 10 of the Treaty between Ukraine and the Republic of Belarus on Friendship, Good Neighborliness and Cooperation (1995). Ukraine terminated the relevant Treaty with the Russian Federation (1997) in 2019 due to material breaches of the treaty's provisions on part of the Russia. It is proved that these articles (norms) can be considered as treaties of the first type, namely inter-state agreements for the promotion of transfrontier cooperation. It has been established that Ukraine has concluded treaties on transfrontier cooperation of the second type, namely inter-state agreements on regional transfrontier liaison, with some neighboring states (the Republic of Poland, the Republic of Moldova, the Republic of Belarus and the Russian Federation). Typically, such intergovernmental agreements contain references to relevant bilateral treaties on good neighborly relations and cooperation, as well as special rules that promote the development of border regions in certain areas of mutual interest. It is determined that the international legal basis for transfrontier cooperation between Ukraine and the European Union, as a legal entity, is the Association Agreement between the European Union and its Member States, of the one part, and Ukraine, of the other part (2014), in particular the Preamble and Chapter 27 of this Agreement is titled as «Cross-border and regional cooperation».

Key words: European Outline Convention on Transfrontier Cooperation, Association Agreement between the European Union and Ukraine, territorial communities and authorities, inter-state agreement for the promotion of transfrontier cooperation, inter-state agreement on regional transfrontier liaison. 